Ethos (Jurnal Penelitian dan Pengabdian Masyarakat): 130-135

\title{
Pemberdayaan Masyarakat Rentan Bencana Nagari Salayo Menuju NAGARI TANGGUH BENCANA
}

\author{
COMMUNITY EMPOWERMENT OF NAGARI SALAYO DisASTER VULNERABLE TO BECOME DisASTER \\ RESILIENT NAGARI \\ ${ }^{1}$ Nasfryzal Carlo, ${ }^{2}$ Yusrita Yanti, ${ }^{3}$ Edi Septe \\ 1, 2,3 Dosen Tetap Universitas Bung Hatta, Kampus Proklamator 1 \\ Jl. Sumatera Ulakkarang, Padang 25135 \\ Email: ${ }^{1}$ carlo@bunghatta.ac.id, ${ }^{2}$ yusritay@yahoo.com, 3 edysepte@yahoo.com
}

\begin{abstract}
The government had been assigned Salayo of village to serve as a disaster resilient village. Build a disaster resilient village to need the stages and processes to the local community. The process is carried out by the method of PRA (Participatory Rural Appraisal) and community action approach that involve (i) education aspects by providing knowledge and training on disaster and risks as well as the impact of the disaster, (ii) planning aspects through empowerment and practice together with the community to identify hazards and disaster risks, and then planned community action corresponding to the location based on the threat of disasters, (iii) implementation aspects of community action based on priority (iv) organizational aspects and the capacity building through the establishment of disaster preparedness group (KSB). The results show a number of identification of community action plans along with implementation according to the capability of local resources, The actions have been done based on priority with limited time and resources. Disaster preparedness groups (KSB) have been unveiled by local the government.

Keywords: community action, disaster preparedness groups (KSB), villages Salayo
\end{abstract}

\begin{abstract}
Abstrak. Nagari Salayo telah ditetapkan oleh pemerintah untuk dijadikan sebagai nagari tangguh bencana. Membangun sebuah nagari menuju tangguh bencana memerlukan tahapan dan proses yang harus dilakukan kepada masyarakat setempat. Proses tersebut dilakukan melalui proses pembelajaran dengan metoda PRA (Participatory Rural Appraisal) dan aksi komunitas dengan pendekatan: (i) Aspek pendidikan dengan memberi pengetahuan dan pelatihan tentang bencana dan risiko serta dampak dari bencana, (ii) Aspek perencanaan, melalui pemberdayaan dan praktek bersama untuk mengidentifikasi bahaya dan risiko bencana, kemudian direncanakan aksi komunitas yang sesuai pada lokasi berdasarkan ancaman bencana yang akan terjadi, (iii) Aspek pelaksanaan dengan melakukan aksi komunitas berdasarkan skala prioritas (iv) Aspek kapasitas organisasi dan kelompok masyarakat melalui pembentukan Kelompok Siaga Bencana (KSB). Hasil menunjukan bahwa sejumlah rencana aksi komunitas telah teridentifikasi dengan kondisi terkini, aksi komunitas telah dilakukan berdasarkan skala prioritas dengan keterbatasan waktu dan sumberdaya yang ada. KSB telah terbentuk dan telah dikukuhkan oleh pemerintah setempat.

Kata kunci: aksi komunitas, kelompok siaga bencana, nagari Salayo
\end{abstract}

\section{Pendahuluan}

Nagari Salayo merupakan salah satu dari 8 nagari yang terdapat di Kecamatan Kubung Kabupaten Solok. Posisi Nagari Salayo berada ditengah-tengah Kecamatan Kubung dengan jarak $3 \mathrm{~km}$ dari pusat Kota Solok, $21 \mathrm{~km}$ dari Arosuka, ibukota Kabupaten Solok, dan $60 \mathrm{~km}$ dari Kota Padang, ibukota Provinsi Sumatera Barat (Witrianto, 2010). Wilayah Nagari Salayo dibagi atas 4 jorong/desa yaitu Jorong Batu 
Palano, Jorong Galanggang Tangah, Jorong Sawah Suduik, dan Jorong Lurah Nan Tigo. Luas nagari Salayo adalah $21,44 \mathrm{~km}^{2}$, terletak pada ketinggian $390-550 \mathrm{~m}$ dari permukaan laut dengan curah hujan $2.141 \mathrm{~mm}$ per tahun dan rata-rata hari hujannya 145,1 hari per tahun. Nagari Salayo mempunyai batas-batas, sebelah utara berbatasan dengan Kota Solok, sebelah selatan berbatasan dengan Nagari Gantung Ciri, sebelah barat dengan Nagari Kotohilalang dan Bukit Barisan, sebelah timur dengan Nagari Kotobaru.

Pemerintah telah menetapkan nagari Salayo sebagai salah satu nagari tangguh bencana. Penetapan ini merupakan perwujudan Program Desa Tangguh Bencana di Sumatera Barat (Carlo, dkk 2016). Menurut Anon (2012), program desa tangguh merupakan salah satu upaya pengurangan risiko bencana berbasis masyarakat. Pengurangan risiko berbasis masyarakat ini adalah segala bentuk upaya untuk mengurangi ancaman bencana dan kerentanan masyarakat, guna meningkatkan kapasitas kesiapsiagaan yang direncanakan dan dilaksanakan oleh masyarakat sebagai pelaku utama.

Lebih lanjut Anon (2012), menjelaskan bahwa tujuan diadakan desa/nagari tangguh adalah untuk (i) melindungi masyarakat yang tinggal di kawasan rawan bahaya dari dampak-dampak merugikan, (ii) meningkatkan peran serta masyarakat, khususnya kelompok rentan dalam pengelolaan sumberdaya dalam rangka mengurangi risiko bencana, (iii) meningkatkan kapasitas kelembagaan masyarakat dalam pengelolaan sumberdaya dan pemeliharaan kearifan lokal bagi pengurangan risiko bencana, (iv) meningkatkan kapasitas pemerintah dalam memberikan dukungan sumberdaya dan teknis bagi pengurangan risiko bencana, (v) meningkatkan kerjasama antara para pemangku kepentingan dalam pengurangan risiko bencana, pihak pemerintah daerah, sektor swasta, perguruan tingi, LSM, organisasi masyarakat dan kelompok-kelompok lain yang peduli.

Untuk mewujudkan nagari tangguh tersebut diperlukan program-program pengurangan risiko bencana dengan target mencapai 20 indikator (Anon, 2012), yaitu (1) adanya kebijakan/peraturan di nagari tentang $\mathrm{PB} / \mathrm{PRB}$, (2) adanya rencana penanggulangan bencana, rencana aksi komunitas, dan/atau rencana kontijensi, (3) terbentuknya forum PRB, (4) terbentuknya relawan penanggulangan bencana di nagari (kelompok siaga bencana), (5) adanya kerjasama antar pelaku dan antar wilayah, (6) disediakan dana tanggap darurat, (7) disediakan dana untuk PRB, (8) dilakukan pelatihan untuk pemerintah desa/kelurahan, (9) adanya pelatihan untuk tim relawan, (10) adanya pelatihan untuk warga desa/kelurahan, (10) adanya pelibatan/partisipasi warga, (12) adanya keterlibatan perempuan dalam tim relawan, (13) tersedianya peta dan analisa risiko, (14) adanya peta dan jalur evakuasi serta tempat pengungsian, (15) tersedianya sistem peringatan dini, (16) dilakukan pelaksanaan mitigasi struktural fisik, (17) adanya pola ketahanan ekonomi untuk mengurangi kerentanan masyarakat, (18) adanya perlindungan kesehatan kepada kelompok rentan, (19) adanya pengelolaan sumber daya alam (SDA) untuk PRB, dan (20) adanya perlindungan aset produktif utama masyarakat.

Berdasarkan target tersebut maka dilakukan program pengurangan risiko bencana yang sesuai untuk masyarakat nagari Salayo secara bertahap. Dengan program tersebut masyarakat terlibat aktif dalam mengkaji, menganalisis, menangani, memantau, mengevaluasi dan mengurangi risiko-risiko bencana yang ada di wilayah mereka, terutama dengan memanfaatkan sumberdaya lokal dan mengintegrasikan dengan kebijakan pembangunan keberlanjutan (Benson, dkk, 2007). 
Hal itu dapat dilakukan melalui sebuah proses yang dimulai sejak dini, mulai dari wilayah terkecil, mulai dari diri sendiri, keluarga kemudian kelompok masyarakat. Untuk mencapai proses dimaksud diperlukan pengetahuan tentang ancaman dan risiko bencana, bagaimana mengantisipasi dan menghindari bencana tersebut. Dengan memiliki pengetahuan dan pemahaman secara bersama-sama dalam masyarakat akan dapat beradaptasi terhadap potensi ancaman dan risiko bencana yang ada dan kemudian dapat melakukan adaptasi serta mitigasi untuk mempercepat pemulihan ketika bencana terjadi sehingga menjadi tangguh.

Membangun ketangguhan masyarakat terhadap bencana bukanlah hal yang mudah tetapi memerlukan bimbingan (pendampingan) atau pemberdayaan sebagaimana dituntut oleh tujuan. Untuk mempercepat tercapainya ketangguhan masyarakat tersebut akan dilakukan serangkaian kegiatan melalui program KKN-PPM Universitas Bung Hatta di Nagari Salayo, Kecamatan Kubung, Kabupaten Solok, Provinsi Sumatera Barat pada tahun 2016.

\section{Metodologi Penelitian}

Masyarakat nagari Salayo pada masing-masing jorong (Jorong Sawah Suduik, Lurah Nan Tigo, Gelanggang Tangah, dan Batu Palano) diberi pengetahuan tentang bencana dan ancaman dari gempa, banjir dan longsor, dan angin puting beliung. Berdasarkan pengetahuan tersebut dilakukan rembuk warga untuk membentuk kelompok siaga bencana (KSB). Selanjutnya KSB bersama masyarakat masing-masing jorong dengan bantuan fasilitator (mahasiswa peserta $\mathrm{KKN}$ ) mengidentifikasi ancaman dan kerentanan pada kondisi terkini. Kemudian dilanjutkan dengan identifikasi rencana aksi dengan metoda PRA (Participatory Rural Apparisal). Berdasarkan hasil identifikasi rencana aksi kemudian dilakukan aksi komunitas prioritas yang sesuai dengan keterbatasan sumberdaya yang ada.

\section{Hasil dan Pembahasan}

\section{Pemberdayaan dan Pembelajaran}

Pemberdayaan dan pembelajaran sangat berguna bagi masyarakat untuk menentukan kerentanan dan masalah yang dihadapi pada kondisi terkini dikaitkan dengan ancaman yang mereka terima. Terdapat empat ancaman yang dihadapi masyarakat nagari Salayo yaitu gempa bumi, banjir dan longsor, angin putting beliung, dan dampak akibat perubahan iklim.

Selain gempa bumi yang mengancam masyarakat nagari Salayo, banjir merupakan ancaman utama pada kawasan jorong Gelanggan Tangah. Hampir setiap tahun banir terjadi akibat meluapnya Batang Lembang (Carlo, dkk, 2016). Jorong Sawah Suduik menerima limpahan/banjir kiriman dari Jorong Gelanggang Tangah. Banjir ini diperparah dengan banyaknya sampah berserakan pada saluran-saluran drainase dan Batang Lembang.

Pada jorong Lurah Nan Tigo, ancaman utama adalah lahan kritis dan kekeringan yang disebabkan oleh pengaruh perubahan iklim. Bencana hama juga sering terjadi berupa hama tikus, hama babi, dan hama wereng terhadap tanaman padi masyarakat setempat. Beberapa rumah penduduk berada dikaki bukit mempunyai potensi lonsornya tanah pada posisi tebing.

Terdapat ancaman bencana longsor dan galodo, angin puting beliung, terganggunya beberapa saluran irigasi yang melewati jorong Batu Palano. Dijumpai 
kawasan Kayu Manang, daerah terisolir di jorong Batu Palano. Pada daerah ini ancaman utama adalah lahan kritis dan longsor dan rendahnya pendidikan anak diusia sekolah.

\section{Rencana Aksi dan Pelaksanaan}

Berdasarkan ancaman dan potensi bencana yang telah teridentifikasi, diperlukan beberapa rencana aksi dan pelaksanaanya guna mengurangi risiko bencana. Adapun rencana aksi dan pelaksanaanya disetiap jorong ditunjukan pada tabel 1 berikut.

\section{Tabel 1: Rencana aksi dan pelaksanaan aksi komunitas}

\begin{tabular}{|c|c|c|c|}
\hline No & Jorong & Rencana Aksi Komunitas & $\begin{array}{l}\text { Pelaksanaan Aksi Komunitas } \\
\text { berdasarkan skala prioritas }\end{array}$ \\
\hline \multirow{4}{*}{1} & \multirow{4}{*}{$\begin{array}{l}\text { Sawah } \\
\text { Suduik }\end{array}$} & Menentukan jalur evakuasi & Menentukan jalur evakuasi \\
\hline & & $\begin{array}{l}\text { Mengidentifikasi tempat kumpul dan } \\
\text { membuat serta memasang rambu evakuasi } \\
\text { pada jalur evakuasi }\end{array}$ & $\begin{array}{l}\text { Mengidentifikasi tempat kumpul, jalur } \\
\text { evaluasi, membuat dan memasang rambu- } \\
\text { rambu jalur evakuaasi dan tempat kumpul }\end{array}$ \\
\hline & & $\begin{array}{l}\text { Memberi penyuluhan dan pembekalan } \\
\text { tentang Bank Sampah }\end{array}$ & $\begin{array}{c}\text { Melakukan pembekalan dan operasional } \\
\text { bank sampah bersama jorong lain } \\
\text { (Gelanggang Tangah) }\end{array}$ \\
\hline & & $\begin{array}{l}\text { Membersihan saluran drainase dari } \\
\text { sampah-sampah }\end{array}$ & $\begin{array}{c}\text { Melaksanakan goro bersama pada saluran } \\
\text { drainase }\end{array}$ \\
\hline \multirow{3}{*}{2} & \multirow{3}{*}{$\begin{array}{l}\text { Lurah } \\
\text { Nan } \\
\text { Tigo }\end{array}$} & Menanam pohon pada lahan kritis & $\begin{array}{l}\text { Menanam pohon pada beberapa lahan } \\
\text { kritis }\end{array}$ \\
\hline & & $\begin{array}{c}\text { Melakukan penyuluhan pertanian tentang } \\
\text { hama wereng dan hama babi serta cara } \\
\text { menanggulangi }\end{array}$ & \\
\hline & & $\begin{array}{l}\text { Melakukan penyuluhan tentang } \\
\text { perubahan iklim, dampak, dan cara } \\
\text { penanggulanginya }\end{array}$ & $\begin{array}{c}\text { Melakukan penyuluhan tentang } \\
\text { perubahan iklim dan dampak serta cara } \\
\text { menanggulanginya }\end{array}$ \\
\hline \multirow{5}{*}{3} & \multirow{5}{*}{$\begin{array}{l}\text { Batu } \\
\text { Palano }\end{array}$} & Membersihkan jalur evakuasi & $\begin{array}{l}\text { Melaksanakan gotong royong bersama } \\
\text { pada jalur evakuasi }\end{array}$ \\
\hline & & $\begin{array}{l}\text { Merancang dan membuat serta dan } \\
\text { memasang rambu-rambu evakuasi dan } \\
\text { titik kumpul. }\end{array}$ & $\begin{array}{l}\text { Membuat dan memasang rambu evakuasi } \\
\text { pada jalur evakuasi }\end{array}$ \\
\hline & & $\begin{array}{l}\text { Menanam pohon yang sesuai pada daerah } \\
\text { kritis potensi bencana longsor dan galodo } \\
\text { terutama pada daerah Kayu Manang }\end{array}$ & $\begin{array}{l}\text { Menanam pohon pada lahan kritis di } \\
\text { daerah Kayu Manang }\end{array}$ \\
\hline & & $\begin{array}{l}\text { Melakukan penyuluhan tentang } \\
\text { pentingnya pendidikan di usia dini. }\end{array}$ & $\begin{array}{c}\text { Memberi penyuluhan tentang pentingnya } \\
\text { pendidikan pada usia dini di daerah Kayu } \\
\text { Manang }\end{array}$ \\
\hline & & $\begin{array}{c}\text { Memperbaiki saluran irigasi dan drainase } \\
\text { yang rusak }\end{array}$ & Memperbaiki saluran irigasi yang rusak \\
\hline \multirow{4}{*}{4} & \multirow{4}{*}{$\begin{array}{l}\text { Gelang } \\
\text { gang } \\
\text { Tangah }\end{array}$} & $\begin{array}{c}\text { Merancang dan membuat serta memasang } \\
\text { rambu evakuasi dan titik kumpul pada } \\
\text { tempat yang sesuai. }\end{array}$ & $\begin{array}{c}\text { Membuat dan memasang rambu-rambu } \\
\text { evakuasi pada jalur evakuasi dan tempat } \\
\text { titik kumpul }\end{array}$ \\
\hline & & $\begin{array}{l}\text { Melakukan gotong royong bersama pada } \\
\text { selokan dan daerah potensi mengganggu } \\
\text { aliran air. }\end{array}$ & $\begin{array}{l}\text { Melakukan goro bersama membersihkan } \\
\text { selokan/drainase }\end{array}$ \\
\hline & & $\begin{array}{l}\text { Melakukan penyuluhan dan pembekalan } \\
\text { pembentukan dan operasional bank } \\
\text { sampah pada anggota dan pengurus KSB. }\end{array}$ & $\begin{array}{c}\text { Melakukan pembekalan dan operasional } \\
\text { bank sampah bersama jorong lain (Sawah } \\
\text { Suduik) }\end{array}$ \\
\hline & & $\begin{array}{l}\text { Membuat rambu ketingian air sebagai } \\
\text { pringatan dini untuk melakukan tindakan } \\
\text { evakuasi akibat banjir }\end{array}$ & $\begin{array}{l}\text { Menyiapkan bahan untuk rambu } \\
\text { peringatan dini banjir }\end{array}$ \\
\hline
\end{tabular}


Oleh karena keterbatasan waktu pelaksanaan KKN-PPM, maka tidak semua rencana aksi yang dapat dilakukan seperti penyuluhan pertanian untuk mengurangi ancaman hama wereng, hama babi serta cara menanggulanginya.

\section{Kelompok Siaga Bencana (KSB)}

Berdasarkan rembuk warga pada masing-masing jorong telah berhasil membentuk KSB dan kepengurusannya pada jorong Sawah Suduik dan jorong Lurah Nan Tigo. Sementara 2 jorong lagi (jorong Gelangang Tangah dan jorong Batu Palano, masyarakat setempat sepakat untuk menyisip/menganti kepengurusan yang sudah meninggal dan tidak aktif. Pengurus KSB merupakan orang-orang terplilih dan mau berkorban dan menjadi relawan bencana. Keempat pengurus KSB tersebut telah dikukuhkan oleh Walinagari Salayo pada 13 Agustus 2016. Pengukuhan ini menunujukan bahwa pemerintah mempunyai komitmen yang kuat untuk menjadikan nagari Salayo menuju nagari tangguh bencana sebagaimana diharapkan (Anon, 2012).

\section{Kesimpulan}

Pemberdayaan masyarakat melalui pembelajaran potensi dan ancaman bencana telah bekontribusi bagi masayarakat nagari Salayo sehinga mereka dapat mengidentifikasi potensi dan ancaman bencana yang akan terjadi pada masing-masing jorong. Banjir, longsor, angin putting beliung, dan dampak perubahan iklim merupakan ancaman bagi masyarakat setempat. Untuk mengurangi risiko bencana tersebut telah dilakukan aksi komunitas berupa pemasangan rambu-rambu pada jorong Gelanggang Tangah, Sawah Suduik, dan Batu Palalo, memperbaiki saluran irigasi dan membekalkan KSB dan anggota KSB dalam mengelola sampah dengan Bank Sampah. Aksi penamanan pohon pada daerah lahan kritis telah dilakukan pada jorong Batu Palano dan Lurah Nan Tigo. Namun ancaman terhadap hama pertanian dan pemasangan rambu ketinggian air sebagai peringatan dini untuk banjir belum dapat dilakukan karena keterbataan waku pelaksanaan KKN-PPM. Disarankan pemerintahan nagari untuk mendatangkan ahli pertanian dari dinas terkait untuk mengurangi ancaman terhadap pertanian masyarakat dan KSB dapat melanjutkan pememasangan rambu peringatan dini terhadap banjir di jorong Gelanggang Tangah.

\section{Ucapan Terima Kasih}

Terima kasih dan penghargaan yang tinggi disampaikan kepada semua pihak yang telah berkontribusi dalam pelaksanaan kegiatan ini (Dirjen Dikti, rektor dan panitia KKN Universitas Bung Hatta, pemerintah kabupaten Solok, walinagari, wali jorong, masyarakat nagari Salayo ,dan mahasiswa peserta KKN-PPM tahun 2016).

\section{Daftar pustaka}

Anon. (2012). Peraturan Penangulangan Bencana nomor 1 Tahun 2012 tentang Pedoman Umum Desa/Kelurahan Tangguh Bencana. BNPB.

Bemson, C., Twigg, T., dan Rossetto, T. (2007). Tools for Mainstreaming Disaster Risk

Reduction: Guidance Notes for Development Organisations. The International Federation of Red Cross and Red Crescent Societies/the ProVention Consortium.

Carlo, N. (2011). Bank Sampah, Siapa Peduli? Teras Utama dalam Harian Padang Ekpres. Senen, \& Maret 2011. 
Carlo, N., Yanti, Y. Septe, E. (2016). Laporan Kemajuan Hibah KKN-PPM, Pemberdayaan Masyarakat Rentan Bencana Nagari Salayo, Kecamatan Kubung, Kabupaten Solok Guna Mewujudkan Nagari Tangguh Bencana.

Twigg, J. (2009). Karateristik Masyarakat Tahan Bencana. (sebuah catatan panduan versi 2 November 2009). Terjemahan Tim Penterjemah Terra Prima Indonesia. Plan Internasional Indonesia dan Oxfam Indonesia.

Witrianto. (2010). Nagari Salayo Kecamatan Kubung Kabupaten Solok. http://witrianto.blogdetik. com/2010/12/10/tata-ruang-tradisional-nagari-selayo/ diakses 12 Maret 2015. 